\title{
Efecto de la adición de lodos de papel activados térmicamente en las propiedades mecánicas y de porosidad de pastas de cemento
}

\section{Effect of thermally activated paper sludge on the mechanical properties and porosity of cement pastes}

\author{
O. Rodríguez ${ }^{(*)}, \underline{\text { M. Frías }}^{(*)}$, M. I. Sánchez de Rojas ${ }^{(*)}$, R. García(**), R. Vigil(**)
}

Recepción/Received: 27-III-07

Aceptación/Accepted: 24-X-07

Publicado online/Online publishing: 17-IV-09

\section{RESUMEN}

El presente trabajo muestra el resultado de una investigación llevada a cabo en pastas de cemento que contienen un 10 y un $20 \%$ de lodo de papel calcinado a $700{ }^{\circ} \mathrm{C}$, durante $2 \mathrm{~h}$. Se estudia cómo afecta esta adición activa en la estructura porosa y las resistencias mecánicas. Se demuestra que tanto la porosidad total como la capilar dependen del porcentaje de lodo calcinado añadido a la matriz cementante. Así, un $10 \%$ de adición muestra para ambas porosidades valores ligeramente superiores al de la pasta de referencia, sin embargo la incorporación de un $20 \%$ produce un resultado contrario, disminuyendo ambas porosidades con respecto a la pasta control. Para el caso de poros de tamaño inferior a $0,01 \mu \mathrm{m}$ (poros de gel) se detecta un importante proceso de refinamiento con la incorporación del lodo calcinado, este refinamiento es tanto mayor cuanto mayor es el porcentaje añadido. En cuanto a los valores de resistencia, para los dos porcentajes de adición se produce una disminución a partir de aproximadamente 15 días, respecto a la pasta patrón. Se muestra una buena correlación entre la porosidad total y la resistencia a compresión para ambas adiciones $\left(R^{2} \geq 0,939\right)$.

Palabras clave: residuos, lodo papel, adición puzolánica, porosidad, resistencia.
SUMMARY

The present article discusses the effect of paper sludge additions, calcined at $700{ }^{\circ} \mathrm{C}$ for two hours, on cement paste pore structure and mechanical strength. Both total and capillary porosity were observed to depend on the percentage of calcined sludge added to the cementitious matrix. While a $10 \%$ addition induced values for both slightly higher than the control, adding $20 \%$ prompted the opposite result, reducing porosity values with respect to the control. Substantial refinement was observed, with a rise in pores smaller than $0.01 \mu \mathrm{m}$ (gel pores) when the calcined sludge was added. Such refinement was greater at the higher percentage of sludge. After approximately 15 days, strength was lower in both the additioned pastes compared to the control. A high correlation $\left(R^{2} \geq 0.939\right)$ was found between total porosity and compressive strength for both percentages studied.

Keywords: waste, paper sludge, pozzolanic addition, porosity, strength.

\footnotetext{
(*) Instituto de Ciencias de la Construcción Eduardo Torroja (CSIC).

(**) Universidad Autónoma de Madrid.
} 


\section{INTRODUCCIÓN}

El aprovechamiento de cualquier subproducto o desecho generado durante un proceso industrial tiene en la actualidad una gran importancia. Una de las formas de reciclar estos subproductos es buscar aplicaciones concretas de uso que se adapten a sus características.

Una de las formas disponibles en el sector de la construcción, para el aprovechamiento de estos residuos sólidos industriales, es su incorporación como adición activa al cemento. Según la norma europea vigente (1) se permite la incorporación de diferentes adiciones activas (humo de sílice, cenizas volantes, puzolanas naturales...).

Es bien conocido que la incorporación de adiciones activas al cemento tiene una influencia directa en las propiedades técnicas de estos nuevos cementos con adición. Uno de los aspectos más importantes es la influencia de estas adiciones sobre la microporosidad y la resistencia de las nuevas matrices cementantes y la relación que existe entre estos dos parámetros (2).

Las causas principales de la variación de estos dos parámetros (porosidad y resistencia) son la relación a/c, el grado de hidratación y la influencia de la reacción puzolánica (2). La hidratación del cemento Portland y la reacción puzolánica causan la disminución de la porosidad de las pastas de cemento con adición. Sin embargo la contribución de la reacción puzolánica en el proceso de rellenar los espacios, se vuelve más importante a medida que avanza la hidratación (3-5).

Este hecho se ve claramente reflejado en los trabajos previos llevados a cabo por Frías y col. (6-8), y Poon y col. (9), entre otros, en los que se demuestra que tras la adición de materiales altamente puzolánicos, metacaolín y humo de sílice, se produce un refinamiento de la estructura porosa por debajo de $100 \AA$.

Debido a que cada adición posee unas características químicas, físicas, morfológicas y mineralógicas determinadas, cada una de ellas tendrá una influencia diferente en las prestaciones de las nuevas matrices cementantes. Por este motivo no se puede generalizar y/o extrapolar a cualquier material puzolánico.

Actualmente las investigaciones se están centrando en una nueva alternativa de utilizar metacaolín reciclado procedente de un lodo originado en la industria papelera por sus beneficios desde el punto de vista de protección del medio ambiente. Hasta el momento existe poca bibliografía acerca de esta línea de investigación. Los estudios pioneros en el tema a nivel mundial fueron llevados a cabo por Pera y col. $(10,11)$, quienes apuntaron la posibilidad de adicionar estos lodos calcinados al

\section{INTRODUCTION}

The re-use of industrial waste and by-products is a priority in today's society. One of the ways to recycle these by-products is to find specific applications suited to their characteristics.

In the construction industry, certain types of solid industrial waste can be used as an active addition in cement. The existing European standard (1) allows the use of a number of active additions (silica fume, fly ash, natural pozzolans...).

The inclusion of active additions to cement is known to have a direct effect on the end product properties relevant to the industry. The effect of such additions on the microporosity and strength of these new cementitious matrices and the relationship between the two are among the major considerations in this regard (2).

The chief causes of variation in cement porosity and strength are the $w / c$ ratio, the degree of hydration and the effect of the pozzolanic reaction (2). While in additioned cement pastes, Portland cement hydration and the pozzolanic reaction both reduce porosity, the contribution of the latter to the gap-filling effect rises with hydration time (3-5).

This finding was clearly observed in prior studies conducted by Frías et al. (6-8) and Poon et al. (9), among others, which showed that adding highly pozzolanic materials such as metakaolin or silica fume refined the pore structure, occasioning a rise in the fraction smaller than $100 \AA$.

Since every addition has distinct chemical, physical, morphological and mineralogical characteristics, the effect of each on the features of the new cementitious matrices varies. This renders generalizations and extrapolations to all pozzolans unfeasible.

Current research is focusing on a new possibility, the use of metakaolin from paper industry sludge, in light of the environmental benefits afforded. Little has been published in the literature to date about this line of research. The pioneer studies on the subject were conducted by Pera et al. $(10,11)$, who suggested that, once calcined, this sludge could be used as a pozzolanic addition in cement. Bai et al (12) subsequently confirmed the good behaviour of pastes 
cemento como adición puzolánica. Posteriormente, Bai y col. (12) estudiaron el buen comportamiento de las pastas que contienen lodo papel y escoria granulada.

Los primeros estudios realizados en España con lodos procedentes de la industria papelera se llevaron a cabo por Frías y col. (13-17). En estos trabajos se caracterizaron dichos lodos, comprobándose que tienen un alto contenido en materia orgánica, la fracción mineral está compuesta por calcita, caolinita, cuarzo y filosilicatos (talco, micas...). Además se confirmó que los lodos de papel calcinados a temperaturas controladas puede ser una vía alternativa de obtener metacaolín, diferente de la vía habitual de calcinar caolinita natural. Posteriormente, se estudió el efecto de estos residuos calcinados sobre las propiedades reológicas de los cementos obtenidos tras su adición.

Teniendo en cuenta los escasos estudios experimentales sobre la incorporación de lodos calcinados como nuevos materiales puzolánicos, se hace imprescindible un mayor conocimiento de su influencia en los aspectos técnicos tan importantes por su repercusión en las prestaciones y especialmente en la durabilidad de las nuevas matrices cementantes.

Por estos motivos, este artículo aborda por primera vez la influencia de un lodo de papel calcinado en la evolución de la porosidad y resistencias a compresión de las nuevas matrices cementantes. Los resultados de este artículo forman parte de un proyecto más extenso acerca del estudio de estos residuos industriales.

\section{EXPERIMENTAL}

\subsection{Materiales}

Los materiales utilizados en este trabajo fueron: cemento y un lodo de papel procedente de una empresa papelera española calcinado a distintas temperaturas. Estas temperaturas van desde 700 hasta $800^{\circ} \mathrm{C}$, y se utilizan dos tiempos de permanencia en el horno, 2 y 5 horas. Así, se obtienen 5 lodos calcinados denominados LPC1LPC5, que corresponden a las calcinaciones a $700{ }^{\circ} \mathrm{C}$ durante 2 horas (LPC1), $700{ }^{\circ} \mathrm{C}$ durante 5 horas (LPC2), $750{ }^{\circ} \mathrm{C}$ durante $2 \mathrm{~h}$ (LPC3), y así sucesivamente.

Cemento: el cemento patrón utilizado fue del tipo CEM I $42,5 \mathrm{R}$, con un contenido de clínker mayor o igual al $95 \%$, y que puede contener un $5 \%$ de componentes minoritarios de acuerdo con la normativa europea (1),

Lodos de papel calcinados (LPC): las composiciones químicas tanto del lodo de partida como de los lodos calcinados, determinados por FRX, aparecen en la Tabla 1. containing paper sludge and granulated blast furnace slag.

The earliest Spanish studies on paper industry sludge were conducted by Frías et al (13-17). According to their findings, sludge has a high organic matter content and a mineral fraction comprising calcite, kaolinite, quartz and phyllosilicates (talc, micas...). They also showed that paper sludge calcined at controlled temperatures may be an alternative to the conventional procedure for obtaining metakaolin by calcining natural kaolinite. Subsequent studies have been conducted to explore the effect of this calcined waste on the rheological properties of the cements generated.

Given the scant experimental work done on the use of calcined sludge as a new pozzolanic material, a fuller understanding of its effect on the relevant practical characteristics of cement is needed to evaluate the respective impact on the features, particularly durability, of these new cementitious matrices.

In light of the foregoing, the present article addresses the effect of calcined paper sludge on the porosity and strength of the resulting cementitious matrices, an area of research not previously explored. The findings discussed here form part of a broader project on the potential use of this industrial waste.

\section{EXPERIMENTAL}

\subsection{Materials}

The materials used in this study were: cement and paper sludge from a Spanish paper mill calcined at temperatures ranging from 700 to $800^{\circ} \mathrm{C}$, and two firing times, two and five hours. The result was five calcined sludge materials, designated CPS1-CPS5, as follows: CPS1 -calcined at $700^{\circ} \mathrm{C}$ for two hours; CPS2- at $700^{\circ} \mathrm{C}$ for five hours; CPS-3 - $750{ }^{\circ} \mathrm{C}$ for two hours and so on.

Cement: the control cement was European standard (1)-compliant CEMI $42.5 R$, containing $95 \%$ clinker or more.

Calcined paper sludge (CPS): the chemical composition of both the initial and the calcined sludge, determined with $X R F$, are given in Table 1 . The results obtained 
Tabla 1 / Table 1

Composición química de los lodos de papel. Chemical composition of paper sludge.

\begin{tabular}{|c|c|c|c|c|c|c|}
\hline Óxidos / Oxides & $\begin{array}{l}\text { Lodo partida / } \\
\text { Raw sludge (\%) }\end{array}$ & $\begin{array}{c}\text { LPC1 / } \\
\text { CPS1 (\%) }\end{array}$ & $\begin{array}{c}\text { LPC2 / } \\
\text { CPS2 (\%) }\end{array}$ & $\begin{array}{c}\text { LPC3 I } \\
\text { CPS3 (\%) }\end{array}$ & $\begin{array}{c}\text { LPC4 / } \\
\text { CPS4 (\%) }\end{array}$ & $\begin{array}{c}\text { LPC5 I } \\
\text { CPS5 (\%) }\end{array}$ \\
\hline $\mathrm{SiO}_{2}$ & 18.01 & 30.2 & 33.4 & 34.9 & 34.7 & 35.7 \\
\hline $\mathrm{Al}_{2} \mathrm{O}_{3}$ & 10.14 & 18 & 19.5 & 20.2 & 20.2 & 20.5 \\
\hline $\mathrm{Fe}_{2} \mathrm{O}_{3}$ & 0.55 & 0.7 & 0.8 & 0.8 & 0.8 & 0.8 \\
\hline $\mathrm{CaO}$ & 19.82 & 31.4 & 32.2 & 32.7 & 33.2 & 33.5 \\
\hline $\mathrm{MgO}$ & 2.58 & 3.7 & 4.3 & 4.4 & 4.3 & 4.6 \\
\hline $\mathrm{SO}_{3}$ & 0.33 & 0.27 & 0.2 & 0.31 & 0.5 & 0.31 \\
\hline $\mathrm{K}_{2} \mathrm{O}$ & 0.21 & 0.32 & 0.29 & 0.32 & 0.32 & 0.33 \\
\hline $\mathrm{Na}_{2} \mathrm{O}$ & 0.25 & 0.21 & 0.16 & 0.19 & 0.19 & 0.2 \\
\hline $\mathrm{TiO}_{2}$ & 0.26 & 0.35 & 0.39 & 0.38 & 0.39 & 0.4 \\
\hline $\mathrm{P}_{2} \mathrm{O}_{5}$ & 0.1 & 0.19 & 0.14 & 0.15 & 0.16 & 0.16 \\
\hline $\mathrm{Cl}^{-}$ & 0.04 & 0.02 & 0.02 & 0.02 & 0.02 & 0.02 \\
\hline P.P.C & 47.62 & 14.53 & 8.49 & 5.47 & 5.13 & 3.42 \\
\hline
\end{tabular}

Los resultados obtenidos ponen de manifiesto que los lodos de papel están formados principalmente por sílice, alúmina y óxido de calcio. La pérdida por calcinación (P.P.C) se calculó según la norma vigente (18).

\subsection{Preparación de las mezclas y curado}

La preparación de mezclas (cemento Portland (CP) + adición) se realizó en un mezclador de polvo de alta velocidad para homogeneizar la mezcla. Dichas mezclas se realizaron siguiendo las siguientes proporciones en peso:

Cemento/LPC: $90 / 10$

Cemento/LPC: 80/20

Referencia: $100 / 0$

Con estas mezclas se prepararon pastas de cemento, donde la proporción agua/mezcla es de 0,5 (esta relación se mantuvo constante para poder hacer comparativos los resultados). Las probetas se realizaron en moldes prismáticos de dimensiones $1 \times 1 \times 6 \mathrm{~cm}$, según el método de Koch-Steinneger (19) y se curaron bajo agua hasta los 28 días.

\subsection{Porosimetría de intrusión de mercurio (PIM)}

Las medidas de porosidad total, capilar (poros de tamaños entre 5 y $0,01 \mu \mathrm{m}$ ) y de gel (poros de tamaño por debajo de 0,01 $\mu \mathrm{m}$ ) además de las medidas de distribución de tamaño de poro se llevaron a cabo utilizando un porosímetro de intrusión de mercurio (PIM), Micromeritics Autopore IV 9500, capaz de medir diámetros de poro de hasta 0,0067 $\mu \mathrm{m}$. La velocidad de intrusión de mercurio fue de $10 \mathrm{~s}$ para cada condición de equilibrio. La cantidad de muestra fue de aproximadamente $2 \mathrm{~g}$, introducida en el porta muestras en un solo bloque. Dicha muestra se sometió previamente a un proceso de degasificación durante $10 \mathrm{~min}$. showed that the paper sludge consisted primarily in silica, alumina and calcium oxide. Loss on ignition (L.O.I.) was computed as specified in the existing standards (18).

\subsection{Blending and curing}

The blends (Portland cement $(P C)+$ addition) were homogenized in a high speed powder mixer. The proportions by weight used were as follows:

Cement/CPS: $90 / 10$

Cement/CPS: $80 / 20$

Control: 100/0

These blends were then used to prepare cement pastes with a water/cement ratio of 0,5 (this ratio was kept constant throughout to ensure comparability of the results). The prismatic specimens, measuring $1 \times 1 \times 6 \mathrm{~cm}$, were moulded in accordance with the Koch-Steinneger (19) method and cured in water for 28 days.

\subsection{Mercury intrusion porosimetry (MIP)}

Total, capillary (pore sizes from 5 to $0.01 \mu \mathrm{m}$ ) and gel (pore sizes under $0.01 \mu \mathrm{m}$ ) porosity, as well as the pore size distribution, were found with a Micromeretics Autopore IV 9500 mercury intrusion porosimeter, able to measure pore diameters as small as $0.0067 \mu \mathrm{m}$. Mercury intrusion timing was $10 \mathrm{~s}$ per equilibration. Each solid block sample, weighing approximately $2 \mathrm{~g}$, was degasified for 10 minutes prior to testing. 


\subsection{Ensayo de resistencia a compresión}

Las probetas se rompieron a compresión en una prensa modelo IBERTEST AUTOTEST 200/10-SW, equipada con

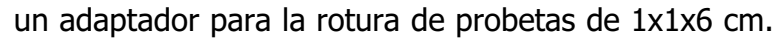

\section{RESULTADOS Y DISCUSIÓN}

\subsection{Actividad puzolánica}

Los resultados de actividad puzolánica no se recogen expresamente en este trabajo, ya que son objeto de un estudio detallado en un trabajo previo (20).

La conclusión de este trabajo (20) es que las condiciones de calcinación más idóneas de todas las estudiadas, desde el punto de vista tanto puzolánico como energético son $700{ }^{\circ} \mathrm{C}$ durante $2 \mathrm{~h}$. Por este motivo se eligen estas condiciones para su posterior estudio en la influencia de la porosidad y las resistencias mecánicas. A partir de este momento, y para evitar confusiones, el lodo calcinado en estas condiciones se denominará LPC.

\subsection{Compressive strength test}

The specimens were compression tested to failure on an IBERTEST AUTOTEST 200/10-SW testing machine fitted with a adapter for $1 \times 1 \times 6-\mathrm{cm}$ specimens.

\section{RESULTS AND DISCUSSION}

\subsection{Pozzolanic activity}

As the findings on pozzolanic activity were the object of a previously published detailed study (20), they are not explicitly discussed here.

The conclusion reached in that study (20) was that for optimal results from both the pozzolanic and energy effectiveness standpoints, the ideal calcining conditions were $700{ }^{\circ} \mathrm{C}$ for two hours. Consequently, these were the conditions chosen in the present study to determine the effect on porosity and mechanical strength. From this point onward, to avoid confusion, the sludge calcined under the above conditions is referred to as CPS.

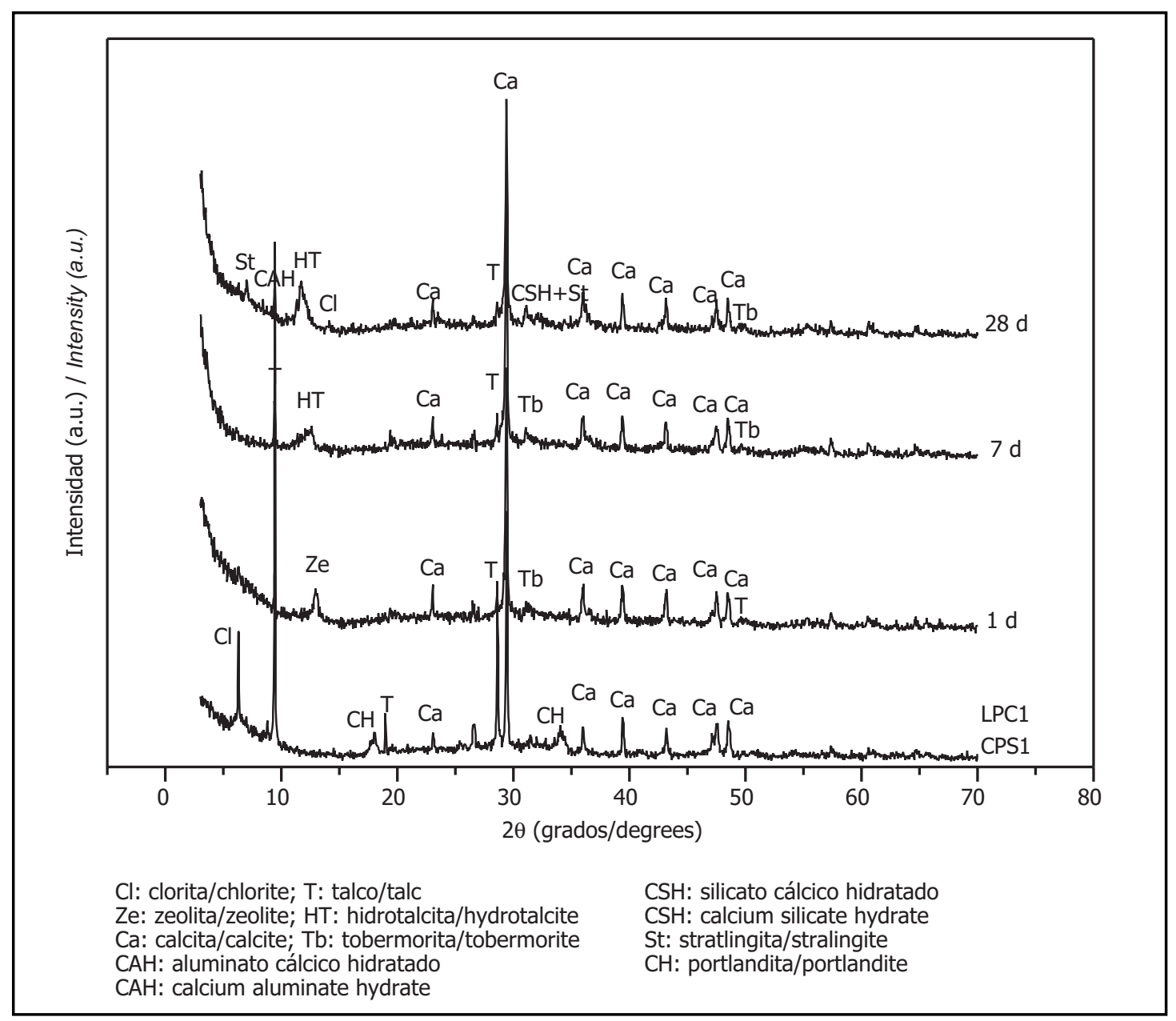

Figura 1. DRX de los productos de la reacción puzolánica.

Figure 1. XRD patterns for pozzolanic reaction products. 
La formación y la evolución de las fases cristalinas hidratadas procedentes de la reacción puzolánica entre el LPC (producto más activo) y la cal fueron caracterizadas mediante DRX, los resultados obtenidos aparecen en la Figura 1.

Se detectaron como productos cristalinos principales de reacción, mediante difracción de Rayos $\mathrm{X}$, zcolitas tipo chabacita (1 día, $2 \theta=9,50^{\circ}, 12,93^{\circ}, 30,59^{\circ}$ ) compuestos de estructura tipo hidrotalcita (en el caso de 7 días de reacción con reflexiones principales a $12,25^{\circ}$ y $23,84^{\circ} 2 \theta$ ), mientras que para 28 días de reacción las reflexiones se aproximan a las correspondientes a la hidrotalcita tipo (de fórmula $\left.\mathrm{Mg}_{6} \mathrm{Al}_{2} \mathrm{CO}_{3}(\mathrm{OH})_{16} .4 \mathrm{H}_{2} \mathrm{O}\right)$ cuya reflexión principal está a $12,92^{\circ} 2 \theta$. Se han reconocido también silicato cálcico hidratado (CSH) (reflexiones a $29,04^{\circ}$ y $31,94^{\circ} 2 \theta$ ), aluminato cálcico hidratado (CAH) con picos a $8,40^{\circ}, 31,02^{\circ}$ y 34,70 $2 \theta$; stratlingita incipiente $\left(7,00^{\circ}\right.$ y $\left.31,09^{\circ} 2 \theta\right)$ y tobermorita con reflexiones principales a $30,06^{\circ}, 31,94^{\circ}$ y $49,78^{\circ} 2 \theta$.

\subsection{Porosidad y distribución de tamaño de poro}

Los datos de porosidad obtenidos mediante porosimetría de mercurio se recogen en la Tabla 2.
The formation and evolution of the hydrated crystalline phases generated during the pozzolanic reaction between CPS (most active product) and lime where characterized with XRD. The results are shown in Figure 1.

The main crystalline reaction products identified with $X$ ray diffraction were chabazite type zcolite ( 1 day, $2 \theta=$ $9.50^{\circ}, 12.93^{\circ}, 30.59^{\circ}$ ) hydrotalcite-type compounds (in

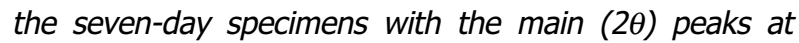
$12.25^{\circ}$ and $\left.23.84^{\circ}\right)$, while the 28-day signals were closer to chabazite-type hydrotalcite $\left(\mathrm{Mg}_{6} \mathrm{Al}_{2} \mathrm{CO}_{3}(\mathrm{OH})_{16} .4 \mathrm{H}_{2} \mathrm{O}\right)$,

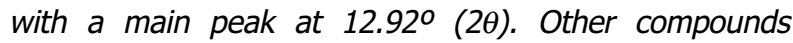

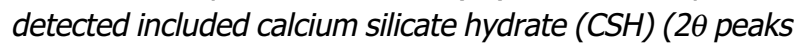
at $29.04{ }^{\circ}$ and $31.94{ }^{\circ}$ ), calcium aluminium hydrate (CAH) with signals at $8.40^{\circ}, 31.02^{\circ}$ and $34.7^{\circ}(2 \theta)$, incipient strätlingite $\left(8.00^{\circ}\right.$ and $\left.31.090,2 \theta\right)$ and tobermorite with peaks at $30.06^{\circ}, 31.94^{\circ}$ and $49.78^{\circ}(2 \theta)$.

\subsection{Porosity and pore size distribution}

The mercury intrusion porosimetry data are given in Table 2.

Tabla 2 / Table 2

Datos de porosidad.

Porosity data.

\begin{tabular}{|c|c|c|c|c|c|c|c|c|c|}
\hline \multirow{2}{*}{$\begin{array}{c}\text { Porosidad (\%) / } \\
\text { Porosity (\%) }\end{array}$} & \multicolumn{3}{|c|}{ CP / PC } & \multicolumn{3}{c|}{$\mathbf{1 0 \%}$ LPC / 10\% CPS } & \multicolumn{3}{c|}{ 20\% LPC / 20\% CPS } \\
\cline { 2 - 11 } & $\mathbf{1 d}$ & $\mathbf{7 d}$ & $\mathbf{2 8 d}$ & $\mathbf{1 d}$ & $\mathbf{7 d}$ & $\mathbf{2 8 d}$ & $\mathbf{1 d}$ & 7d & 28d \\
\hline Total & 35.44 & 27.18 & 26.45 & 35.42 & 29.52 & 26.57 & 33.71 & 24.34 & 22.64 \\
\hline $5-0.01 \mu \mathrm{m}$ & 33.39 & 25.69 & 24.57 & 34.42 & 27.74 & 24.81 & 32.27 & 22.12 & 20.22 \\
\hline$<0.01 \mu \mathrm{m}$ & 0.247 & 0.669 & 0.802 & 0.447 & 1.340 & 1.311 & 0.604 & 1.683 & 1,569 \\
\hline
\end{tabular}

A la edad de 1 día, los valores obtenidos para la porosidad total son semejantes para el caso del $0 \%$ y el $10 \%$ de adición (mostrando un valor aproximado de 35,4\%), mientras que para el $20 \%$ de adición, la porosidad total disminuye a un valor del 33,7\%, lo que supone una ligera disminución frente a las otras pastas realizadas. Con el aumento del tiempo de hidratación hasta los 28 días, se produce una reducción continua de la porosidad total.

La incorporación de un 10 y un $20 \%$ de LPC, no tiene un efecto importante sobre la porosidad total, respecto la pasta de referencia. La mayor variación en la porosidad es de $3,8 \%$, y corresponde a la pasta con un $20 \%$ de adición a los 28 días de hidratación.

En cuanto a la porosidad capilar (5 a 0,01 $\mu \mathrm{m}$ ), se observa un comportamiento similar que para la porosidad total, aumenta ligeramente con el $10 \%$ y disminuye
In the one-day specimens, the total porosity values were similar (at around 35.4\%) for the pastes containing 0\% and $10 \%$ of the addition, while in the $20 \%$ pastes, the total porosity was slightly lower, at $33.7 \%$. Total porosity declined steadily with hydration time up to $t=28$ days.

The addition of 10 or $20 \%$ CPS had no material effect on total porosity. The greatest variation was $3.8 \%$, recorded in the $20 \%$ paste after 28 days of hydration.

Capillary porosity (5 to $0.01 \mu \mathrm{m}$ ) was found to behave similarly, exhibiting slightly higher values than the control in the $10 \%$ CPS pastes and lower values in the 
al adicionar un $20 \%$ de LPC respecto a la pasta de referencia a la misma edad. Una disminución del $4,3 \%$ en la porosidad capilar, tiene lugar en las pastas de cemento con un $20 \%$ de LPC a 28 días de hidratación con respecto a la pasta patrón.

El beneficio de adicionar un material puzolánico, en este caso un lodo de papel calcinado a $700{ }^{\circ} \mathrm{C}$ durante 2 horas (LPC), se observa en los poros tipo gel que tienen un diámetro menor de 0,01 $\mu \mathrm{m}$. Esta porosidad aumenta considerablemente tanto con el porcentaje de adición como con el tiempo de hidratación, es decir, se produce un proceso de refinamiento de la red porosa, al rellenarse los huecos existentes con los productos de la reacción puzolánica.

Este proceso de refinamiento producido por la incorporación de lodos calcinados LPC puede verse claramente en las curvas de distribución de tamaño de poro (Figura 2).

De estas figuras, se puede deducir que en todos los casos al aumentar el tiempo de curado, la frecuencia relativa se desplaza hacia diámetros de poro más pequeños, entre 0,1 y $0,01 \mu \mathrm{m}$. Para el caso de la pasta de referencia, el diámetro de poro disminuye de 0,18 (1 día) a $0,11 \mu \mathrm{m}$ (28 días). Cuando se adiciona un $10 \%$ de LPC, este diámetro varía desde 0,34 hasta $0,11 \mu \mathrm{m}$. Este fenómeno se observa más claramente en el caso del $20 \%$ de adición, la variación se produce desde 0,34 hasta $0,06 \mu \mathrm{m}$, por lo tanto es donde se produce un mayor refinamiento de los tamaños de poro.

Este comportamiento del LPC es similar al de otros productos altamente puzolánicos (humo de sílice, metacaolín) $(21,22)$. Este aumento importante de los poros de gel estaría relacionado con la cinética de reacción entre el lodo calcinado y el $\mathrm{Ca}(\mathrm{OH})_{2}$ liberado durante la reacción de hidratación del cemento Portland.

En un trabajo previo Péra y col. (10) demostraron que durante la reacción puzolánica se forman silicatos cálcicos hidratados y carboaluminato cálcico como fases mineralógicas principales. Posteriormente Frías y col. (13) encontraron, además de las fases anteriores, stratlingita e hidrogranate como otras fases mineralógicas formadas durante la reacción puzolánica, en función de las condiciones de calcinación. Todas estas fases modificarían la red porosa e incidirían directamente en la obtención de una estructura más densa y menos porosa de las matrices con esta adición puzolánica. A este respecto, es importante resaltar que las fases hidratadas mencionadas en las referencias bibliográficas anteriores (8-12) son similares por las obtenidas por Bai y col. (12), quienes trabajaron con lodos de papel calcinados a muy altas temperaturas $\left(1.200^{\circ} \mathrm{C}\right)$ que no contienen metacaolín, sino un silicato dicálcico hidratado que presenta propiedades hidráulicas $\left(\alpha^{\prime}-\mathrm{C}_{2} S\right)$.
$20 \%$ CPS samples at any given age. The decline in the 28-day, 20\% CPS cement paste capillary porosity with respect to the control was $4.3 \%$.

The benefits of adding a pozzolanic material, in this case paper sludge calcined at $700^{\circ} \mathrm{C}$ for two hours (CPS), was observed in the gel-type pores, with a diameter of under $0.01 \mu \mathrm{m}$. This porosity rose substantially with rising proportions of the addition and hydration time both, i.e., inducing pore network refinement because the pozzolanic reaction products filled the existing gaps.

This refinement, induced by the inclusion of CPS calcined sludge, can be clearly seen in the pore size distribution curves in Figure 2.

These curves show that the relative frequency shifted toward smaller pore sizes, between 0.1 and $0.01 \mu \mathrm{m}$, with long curing times. In the control paste, the pore diameter dipped from 0.18 (one day) to $0.11 \mu \mathrm{m}$ (28 days). When $10 \%$ CPS was added, the variation in diameter was from 0.34 to $0.11 \mu \mathrm{m}$. The effect was observed more clearly in the $20 \%$ addition, where the diameter declined from 0.34 to $0.06 \mu \mathrm{m}$. Therefore, pore size refinement was most intense in these pastes.

In this regard, the CPS behaved in much the same way as highly pozzolanic materials (silica fume, metakaolin) $(21,22)$. Such a significant rise in the gel pores would be related to the kinetics of the reaction between the calcined sludge and the $\mathrm{Ca}(\mathrm{OH})_{2}$ released during Portland cement hydration.

In a prior study Pera et al. (10) showed that the main mineralogical phases formed during the pozzolanic reaction are calcium silicate hydrates and calcium carboaluminate. Frias et al. (13) subsequently found that other mineralogical phases, namely strätlingite and hydrogarnet, also formed during that reaction. All these phases would modify the pore network and directly induce the generation of a denser, less porous structure in the matrices when the pozzolan was added. Note in this regard that the hydrated phases mentioned in the above references (8-12) were similar to the phases obtained by Bai et al. (12), who worked at very high temperatures $\left(1,200^{\circ} \mathrm{C}\right)$ with calcined sludge that contained not metakaolin, but a dicalcium silicate hydrate with hydraulic properties $\left(\alpha^{\prime}-C_{2} S\right)$. 

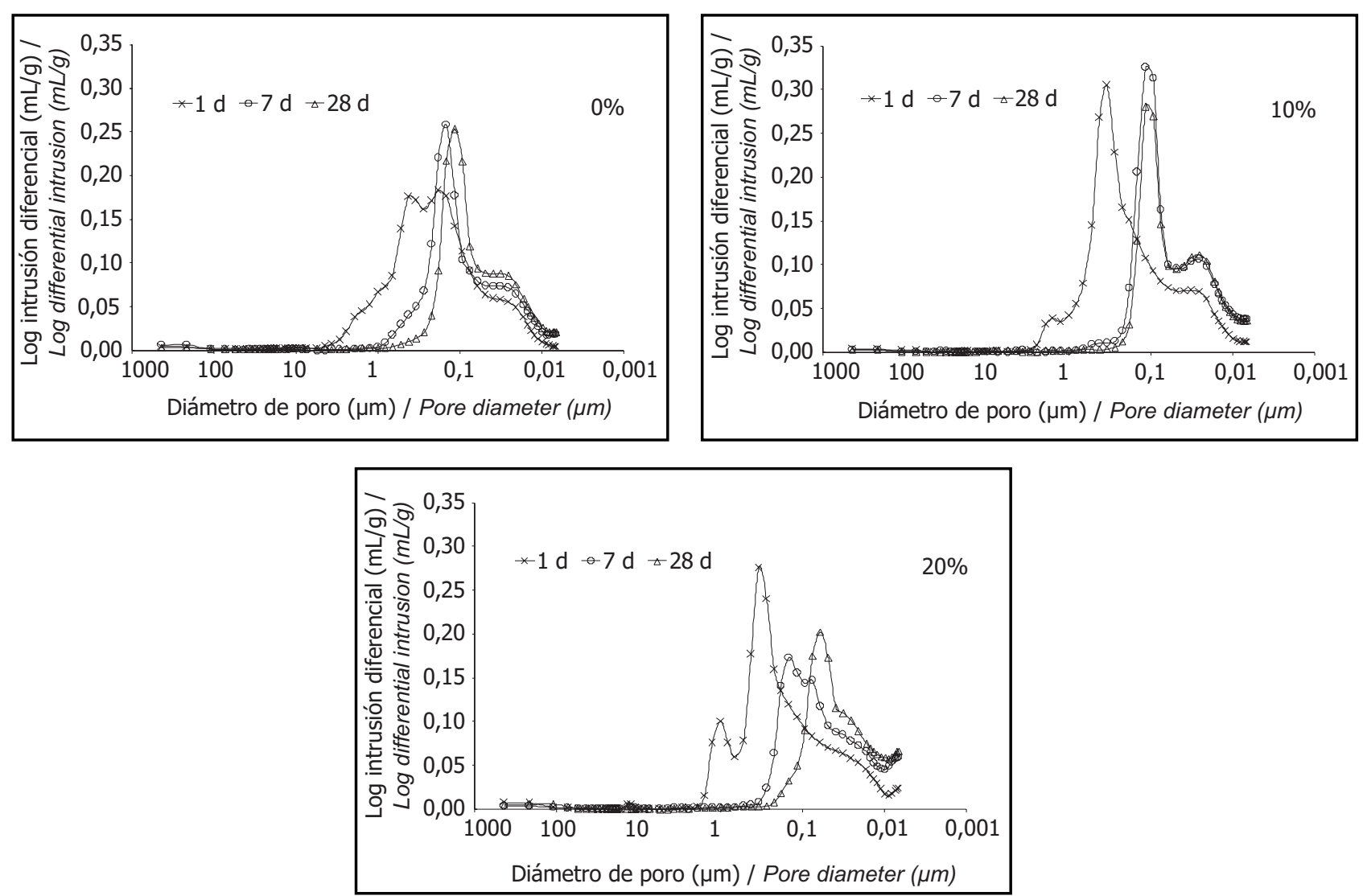

Figura 2. Variación del Log intrusión diferencial frente al diámetro de poro de las diferentes pastas.

Figure 2. Log differential intrusion Log vs. paste pore size.

\subsection{Resistencia a compresión}

Los resultados de resistencia a compresión (Rc) de la pasta de referencia $(0 \%)$ y las pastas con adición (10 y $20 \%$ LPC), curadas hasta 28 días están recogidas en la Figura 3. Cuando ha transcurrido el primer día de hidratación, la resistencia a compresión de las pastas con LPC es superior a la de la pasta de referencia para ambos porcentajes de adición, obteniéndose valores muy similares para ambos porcentajes. Sin embargo a mayores edades se observan dos comportamientos diferenciados, según el porcentaje de lodo calcinado adicionado. En el caso de la adición de $10 \%$ LPC, se observa que el valor de resistencia a compresión es superior al valor obtenido por la pasta patrón hasta los 15 días de curado, alcanzándose posteriormente un resultado inferior a la pasta patrón a los 28 días de curado. Para el caso de la adición del $20 \%$ LPC se detecta que a partir de 5 días de curado las resistencias a compresión son inferiores a la de la pasta de referencia, aunque a los 28 días de curado se obtiene un valor similar que para el $10 \%$ de adición, es decir, el aumento del porcentaje de adición no influye en la resistencia a compresión a 28 días.

La evolución de las resistencias a compresión para las pastas que contienen LPC está directamente relacionada con

\subsection{Compressive strength}

The 28-day compressive strength $\left(R_{c}\right)$ findings for the control (0\%) and additioned (10\% and 20\% CPS) pastes are shown in Figure 3. After the first day of hydration, compressive strength was similar in the two CPSbearing pastes and higher in both than in the control. Nonetheless, at older ages, behaviour varied depending on the percentage of calcined sludge added. In the $10 \%$ CPS paste, the compressive strength value was higher than for the control paste for the first 15 days, but lower after 28 days. While compressive strength was lower in the $20 \%$ CPS paste than in the control after five days, its 28-day strength was similar to the value found for the paste containing $10 \%$ of the addition. In other words, raising the percentage of the addition had no effect on 28-day compressive strength.

As shown, then, the development of compressive strength in CPS-bearing pastes was directly related to 


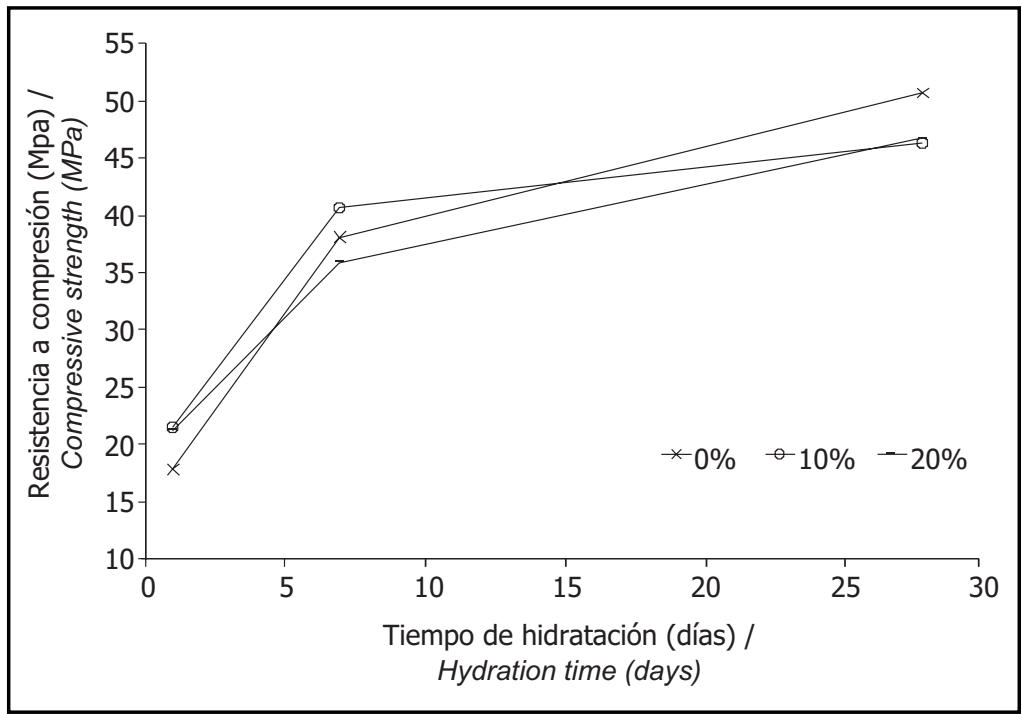

Figura 3. Resistencia a compresión frente al tiempo.

Figure 3. Compressive strength vs. time.

su actividad puzolánica y con la formación de diferentes fases hidratadas, como se refleja en el apartado anterior.

\subsection{Relación entre porosidad total y resistencia a compresión}

La variación de la porosidad, debida a la adición de un producto puzolánico, influye directamente en las resistencias mecánicas de las pastas elaboradas con dicha adición. Para realizar una comparación entre ellos, se representan ambos valores para cada adición (Figura 4).

A la vista de las figuras se deduce que al reducirse la porosidad total aumenta la resistencia a compresión tanto para la pasta patrón ( $0 \%)$, como para las adiciones (10 y $20 \%$ ), esto es debido a que se reduce el tamaño de poro gracias al refinamiento de la red porosa, como se ha comentado anteriormente, debido principalmente tanto a la reacción de hidratación del cemento Portland como a la reacción puzolánica entre el metacaolín (procedente del lodo de papel calcinado) y el hidróxido cálcico. En este caso, el punto de inflexión entre ambos parámetros está situado entre 7 y 15 días de hidratación en las matrices cementantes estudiadas. Estos resultados están de acuerdo con la fórmula propuesta por Hasselman (23) en la que se indica que la resistencia a compresión $\left(R_{c}\right)$ es inversamente proporcional a la porosidad total $\left(P_{t}\right)[1]$ : their pozzolanic activity and the formation of different hydrated phases.

\subsection{Relationship between total porosity and compressive strength}

The variation in porosity induced by the addition of the pozzolanic product directly affected the mechanical strength of the pastes prepared with the addition. The two parameters are compared in Figure 4.

The curves show that compressive strength in both the control and the additioned pastes (10 and 20\%) rose with declining total porosity. As noted earlier, this was because Portland cement hydration and the pozzolanic reaction between the metakaolin (from the calcined paper sludge) and the calcium hydroxide refined the pore network, leading to a reduction in pore size. In this case, the inflection point between the two parameters was located between 7 and 15 days of hydration in the cementitious matrices studied. These findings are consistent with the formula proposed by Hasselman (23), indicating that compressive strength $\left(R_{C}\right)$ is inversely proportion to total porosity $\left(P_{t}\right)[1]$ :

$$
\begin{array}{r}
\mathrm{R}_{\mathrm{c}}=\mathrm{R}_{\mathrm{c} 0}\left(1-\mathrm{b} \mathrm{P}_{\mathrm{t}}\right) \text {, donde } \mathrm{R}_{\mathrm{c} 0} \mathrm{y} \mathrm{b} \text { son constantes } \\
\text { where } R_{c 0} \text { and } b \text { are constants }
\end{array}
$$



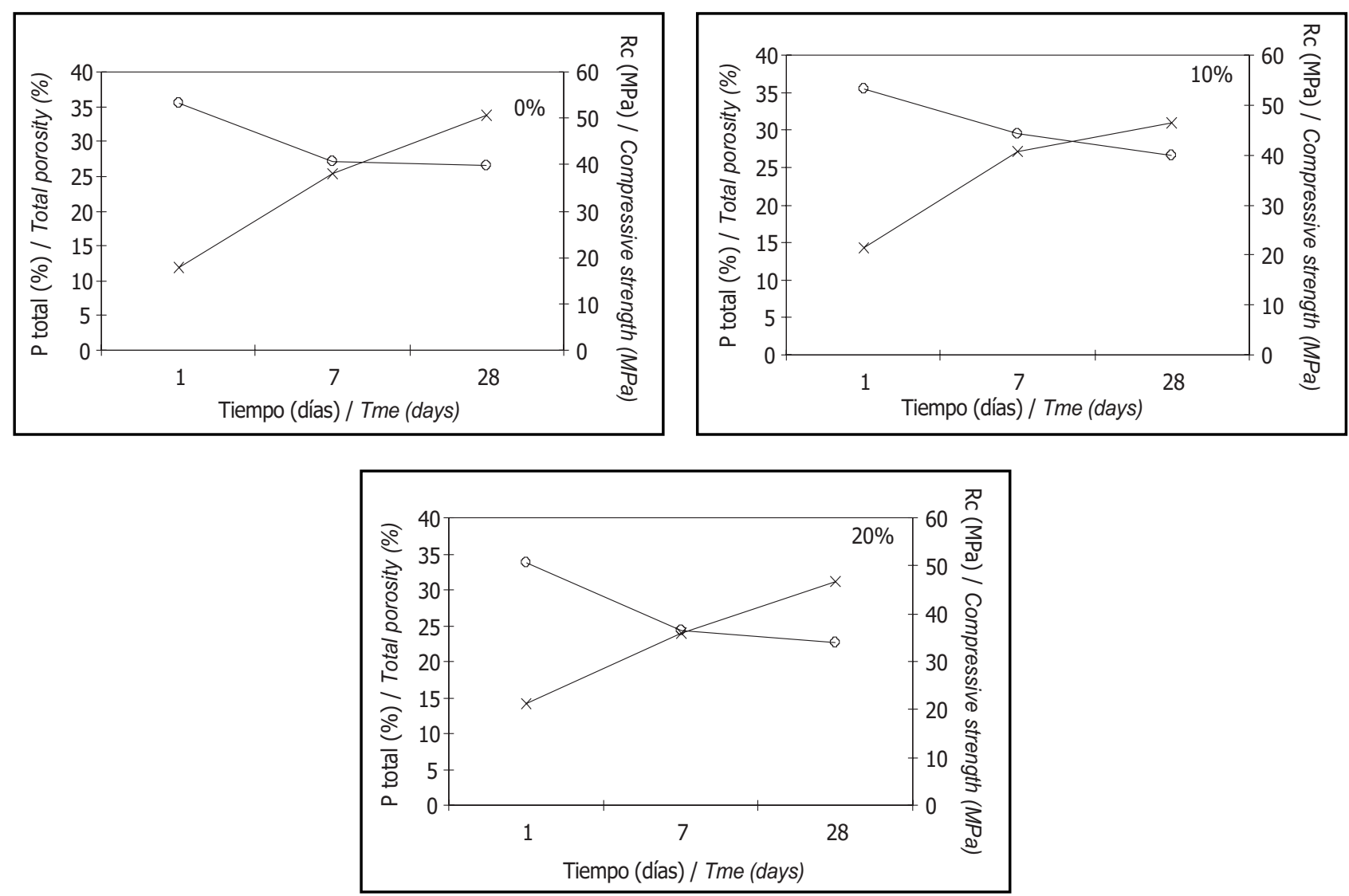

Figura 4. Comparación de la porosidad total y la resistencia a compresión frente al tiempo.

Figure 4. Total porosity and compressing strength vs. time.

Las relaciones estadísticas entre ambos parámetros aparecen en la Figura 5. En ellas se puede observar que existe una relación lineal entre la resistencia a compresión y la porosidad para las distintas adiciones, con buenos coeficientes de correlación $\left(R^{2}=0,9390 ; 0,9882 ; 0,9397\right.$ para el $0 \%, 10 \%$ y $20 \%$ de adición, respectivamente).
The statistical relationships between the two parameters appear in Figure 5. According to the figure, compressive strength and porosity for the different additions are linearly related, with high correlation coefficients $\left(R^{2}=0.9390 ; 0.9882 ; 0.9397\right.$ for the 0,10 and $20 \%$ additions, respectively).

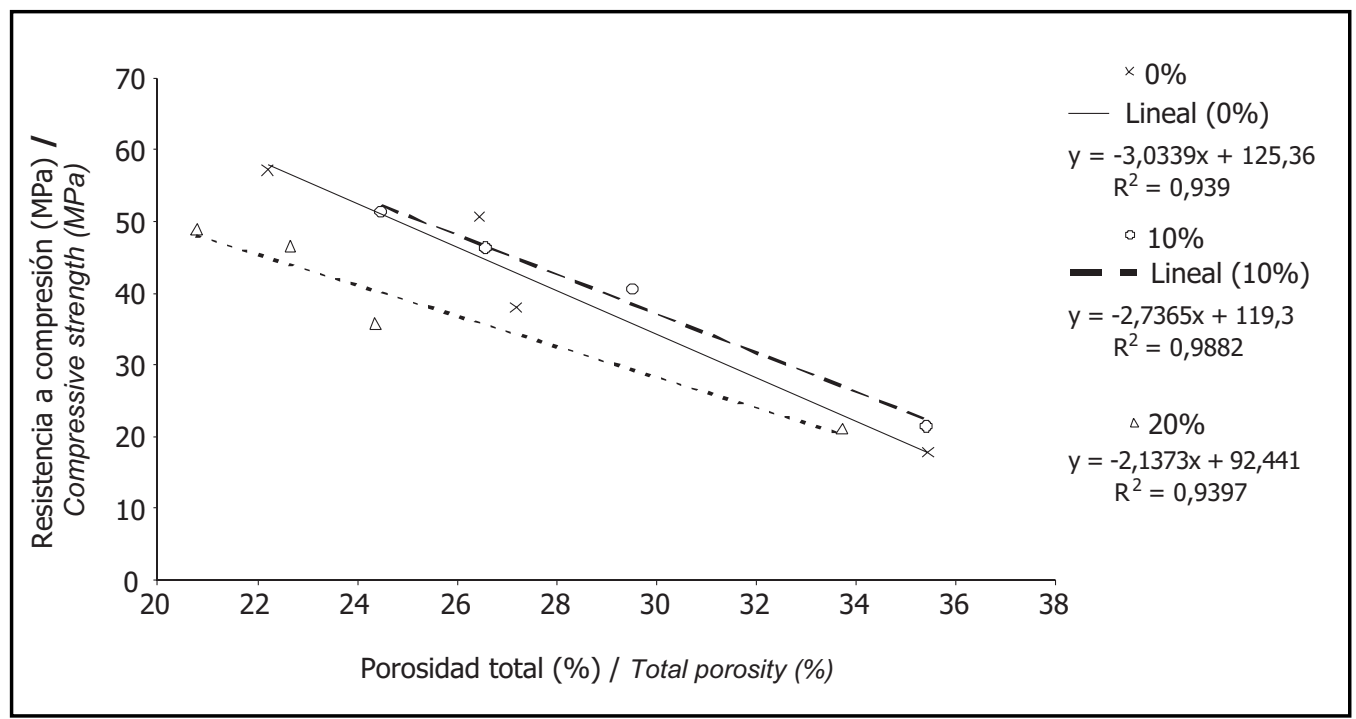

Figura 5. Relación lineal entre $R_{c}$ y $P_{t}$.

Figure 5. Linear relationship between strength and total porosity. 


\section{CONCLUSIONES}

De los resultados obtenidos en el presente trabajo, se concluye que:

1. La porosidad total se reduce a los 28 días con la adición de LPC, observándose un comportamiento similar para la porosidad capilar. Sin embargo, en cuanto a los poros de tamaño menor a $0,01 \mu \mathrm{m}$, se observa un aumento de dichos poros tipo gel, produciéndose un refinamiento de la red porosa, al aumentar la cantidad de LPC adicionado.

2. Los valores de resistencia a compresión obtenidos para las pastas con adición (10 y $20 \%$ LPC) no modifican en gran medida los valores del cemento Portland, sin embargo, se observa un aumento de las resistencias a corto plazo, sobre todo en las pastas con un $10 \%$ de lodo calcinado, debido fundamentalmente a la máxima reacción puzolánica de este residuo industrial para este tiempo de hidratación.

3. Al reducirse la porosidad total aumenta la resistencia a compresión tanto para la pasta patrón $(0 \%)$, como para las adiciones (10 y $20 \%$ ), esto queda demostrado mediante la relación lineal que existe entre ambas magnitudes, en todos los casos con valores de coeficiente de correlación $R^{2} \geq 0,939$.

\section{AGRADECIMIENTOS}

Los autores desean agradecer al Ministerio de Educación y Ciencia por la subvención de este proyecto (ref. CTM2006-12551-C03-01/TECNO) y, a la empresa Holmen Paper Madrid S.L., y al IECA por su colaboración en esta investigación.

\section{CONCLUSIONS}

The conclusions to be drawn from the above findings are:

1. Twenty eight-day total and capillary porosity declined with the addition of CPS. By contrast, the number of pores smaller than $0.01 \mu \mathrm{m}$, or gel-type pores, was observed to rise, an indication of pore network refinement at higher percentages of CPS.

2. The compressive strength values obtained for pastes with the addition (10 and 20\% CPS) were not materially different from the values for Portland cement. Nonetheless, the short-term strength was greater, particularly in pastes with $10 \%$ calcined sludge, primarily because the pozzolanic reaction for this industrial waste peaked at that hydration time.

3. Compressive strength grew with declining total porosity in both the control (0\%) and the additioned (10 and 20\%) pastes. This was observed in the linear relationship between the two magnitudes, which in all cases exhibited correlation coefficients of $R^{2} \geq 0.939$.

\section{ACKNOWLEDGEMENTS}

The present study was funded by the Ministry of Education and Science (project ref.: CTM2006-12551-C0301/TECNO). The authors wish to thank Holmen Paper Madrid S.L. and the Spanish Institute of Cement and its Applications (IECA) for their assistance in this research.

\section{BIBLIOGRAFÍA / BIBLIOGRAPHY}

(1) UNE-EN 197-1: "Cemento, Parte 1: Composición, especificaciones y criterios de conformidad de los cementos comunes" (2000).

(2) LEA's: Chemistry of Cement and Concrete, Arnold, Great Britain (1998), p. 536.

(3) Çolak, A.: "Characteristics of pastes from a Portland cement containing different amounts of natural pozzolan". Cem. Concr. Res., vol. 33, no 4 (2003), pp. 585-593.

(4) Saraswathy, V.; Song, H. W.: "Corrosion performance of rice husk ash blended concrete". Constr. Build. Mat., vol. 21, no 8 (2007), pp. 1779-1784. doi:10.1016/j.conbuildmat.2006.05.037

(5) Hossain, K. M. A.; Lachemi, M.: "Strength, durability and micro-structural aspects of high performance volcanic ash concrete". Cem. Concr. Res., vol. 37, no 5 (2007), pp. 759-766. doi:10.1016/j.cemconres.2007.02.014

(6) Frías, M.; Sánchez de Rojas, M. I.: "Influence of the metakaolin on porous structure of matrixes based in MK/cement". Mater. Construcc., vol. 50, no 259 (2000), pp. 57-67.

(7) Frías, M.; Sánchez de Rojas, M. I.: "Microstructural alterations in fly ash mortars: Study on phenomena affecting particle and pore size". Cem. Concr. Res., vol. 27, no 4 (1997), pp. 619-628. doi:10.1016/S0008-8846(97)00026-4

(8) Frías, M.: "The effect of metakaolin on the reaction products and microporosity in blended cement pastes submitted to long hydration time and high curing temperature". Adv. Cem. Res., vol. 18, no 1 (2006), pp. 1-6. doi:10.1680/adcr.2006.18.1.1

(9) Poon, C. S.; Kou, S. C.; Lam, L.: "Compressive strength, chloride diffusivity and pore structure of high performance metakaolin and silica fume concrete". Constr. Build. Mater., vol. 20, no 10 (2006), pp. 858-865. doi:10.1016/j.conbuildmat.2005.07.001 
(10) Pera, J.; Ambroise, J.: "Pozzolanic properties of metakaolin obtained from paper sludge", en Malhotra, V. M. (ed.): Sixth CANMET/ACI, Conference On Fly Ash, Silica Fume, Slag and Natural Pozzolans in Concrete (SP178-52), Bangkok (1998), pp. 1007-1020.

(11) Pera, J.; Amrouz, A.; "Development of highly reactive metakaolin from paper sludge". Adv. Cem. Based Mater., vol. 7, n 2 (1998), pp. 49-56. doi:10.1016/S1065-7355(97)00016-3

(12) Bai, J.; Chaipanich, A.; Kinuthia, J. M.; O'Farrell, M.; Sabir, B. B.; Wild, S.; Lewis, M. H.: "Compressive strength and hydration of wastepaper sludge ash-ground granulated blastfurnace slag blended pastes". Cem. Concr. Res., vol. 33, no 8 (2003), pp. 1189-1202. doi:10.1016/S0008-8846(03)00042-5

(13) Frías, M.; Sánchez de Rojas, M. I.; Rivera, J.: "Influence of calcining conditions on pozzolanic activity and reaction kinetics in paper sludge-calcium hydroxide mixes", en Malhotra, V. M. (ed.): Eighth CANMET/ACI, Conference On Fly Ash, Silica Fume, Slag and Natural Pozzolans in Concrete (SP-221-53), Las Vegas (2004), pp. 879-892.

(14) Banfill, P.; Frías, M.: "Rheology and conduction calorimetry of cement modified with calcined paper sludge". Cem. Concr. Res., vol. 37, no 2 (2007), pp. 184-190. doi:10.1016/j.cemconres.2006.11.013

(15) Vegas, I.; Frías, M.; Urreta, J.; San José, J. T.: "Obtaining a pozzolanic addition from the controlled calcination of paper mill sludge. Performance in cement matrices". Mater. Construcc., vol. 56, no 283 (2006), pp. 49-60.

(16) Sabador, E.; Frías, M.; Sánchez de Rojas, M. I.; Vigil, R.; García, R.; San Jose, J. T.: "Characterization and transformation of an industrial by-product (coated paper sludge) into a pozzolanic material". Mater. Construcc., vol. 57, n० 285 (2007), pp. 45-59.

(17) Frías, M.; Sabador, E.; Ferreiro, S.; Sánchez de Rojas, M. I.; García, R.; Vigil, R.: "Effect of the activation of a clay-base paper industry by-product on cement matrix behaviour". Mater. Construcc., vol. 58, no 292 (2008), pp. 67-70.

(18) UNE-EN 196-2: "Métodos de ensayo de cemento, Parte 2: Análisis químico de cementos" (1994).

(19) Koch, A.; Steinegger, H.: "A rapid method for testing the resistence of cements to sulphate attack". Zement-Kalk-Gips., vol. 7 (1960), pp. 317-324.

(20) Frías, M.; Sánchez de Rojas, M. I.; Rodríguez, O.; García, R.; Vigil, R.: "Characterization of calcined paper sludges as environment friently source of metakaolin for manufacture of cementing matrixes". Adv. Cem. Res., vol. 20, n. 1 (2008), pp. 23-30. doi:10.1680/adcr.2008.20.1.23

(21) Frías, M.; Cabrera, J.: "Pore size distribution and degree of hydration of metakaolin cement pastes". Cem. Concr. Res., vol. 30, no 4 (2000), pp. 561-569. doi:10.1016/S0008-8846(00)00203-9

(22) Khabit, J. M.; Wild, S.: "Pore size distribution of MK paste". Cem. Concr. Res., vol. 26, no 10 (1996), pp. 1545-1553.

(23) Hasselman, D. P. H.: "Relation between effects of porosity on strength and Young's modulus of elasticity of polycrystalline materials". J. Am. Ceram. Soc., vol. 46, no 1 (1963), pp. 564-565. doi:10.1111/j.1151-2916.1963.tb14615.x 